\title{
Pharmacokinetic of florfenicol in pulmonary epithelial lining fluid of swine and effects of anesthetic agent on drug plasma disposition kinetics
}

\author{
[Farmacoqu'imica de florfenicol em fluido de epitélio pulmonar de suínos e efeitos de agente \\ anestésico em cinética de droga em plasma] \\ Yanping Wang ${ }^{1,2}$, Ling Zhang ${ }^{2}$, Saeed Ahmed ${ }^{3}$, Yonghong Liu ${ }^{1}$, Xianqiang Li $^{1 *}$ \\ ${ }^{1}$ College of Animal Science, Tarim University, Key Laboratory of Tarim Animanl Husbandry Science and \\ Technology of Xinjiang Production \& Construction Corps, Aral 843300, China \\ ${ }^{2}$ College of Animal Science and Technology, Shihezi University, Shihezi, Xinjiang, China \\ ${ }^{3}$ National Reference Laboratory of Veterinary Drug Residues (HZAU) and MOA Key Laboratory for the Detection \\ of Veterinary Drug Residues in Foods, Huazhong Agricultural University, Wuhan 430070, China.
}

\begin{abstract}
The primary objective of the current study was to compare the pharmacokinetic (PK) of florfenicol (FFL) in pulmonary epithelial lining fluid and the plasma in swine. The second objectives were to evaluate the effect of anesthesia with ketamine and propofol on the PK of FFL in plasma. Bronchoaveolar lavage was utilized for quantification of PELF volume and the urea dilution method was used to determine the concentration of FFL in PELF. FFL was administered intramuscularly (IM) to swine in a single dose of $20 \mathrm{mg} / \mathrm{kg}$ body weight. The main PK parameters of FFL in plasma and PELF were as follows: the area under the concentration-time curve, maximal drug concentration, elimination half-life and mean residence time were $69.45 \pm 4.36$ vs $85.03 \pm 9.26 \mu \mathrm{g} \cdot \mathrm{hr} / \mathrm{ml}, 4.65 \pm 0.34$ vs $5.94 \pm 0.86 \mu \mathrm{g} / \mathrm{ml}, 9.87 \pm 1.70$ vs $10.69 \pm 1.60 \mathrm{hr}$ and $12.75 \pm 0.35$ vs $14.46 \pm 1.26 \mathrm{hr}$, respectively. There was no statistically significant difference between the PK profiles of FFL for the anesthetized and unanesthetized pigs. This study suggest that (i) FFL penetrated rapidly into the pulmonary and the drug concentration decay faster in plasma than in the pulmonary, (ii) the PK profile of FFL in swine was not interfered after administration of anesthetic agent.
\end{abstract}

Keywords: anesthetic agent, bronchoaveolar lavage, florfenicol, pharmacokinetic, pulmonary

\section{RESUMO}

O objetivo primário desse estudo foi comparar a farmacocinética de florfenicol (FFL) em fluido epitelial pulmonar à farmacocinética $(P K)$ de FFL em plasma suíno. O segundo objetivo foi avaliar o efeito de anestesia com ketamina e propofol no PK de FFL em plasma. Lavagem broncoalveolar foi utilizada para quantificar volume de fluido epitelial pulmonar (PELF) e método de diluição de uréia para determinar FFL em PELF. Injeção de FFL foi administrada intramuscular a suínos em dose única de 20mg/kg de peso corporal. Os principais parâmetros de PK em FFL em plasma e PELF foram os seguintes: a área sob a curva de concentração-tempo, concentração máxima da droga, eliminação de meia-vida e média

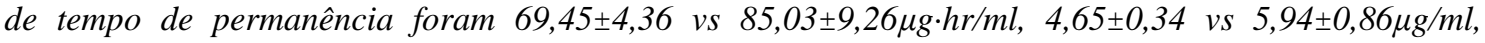

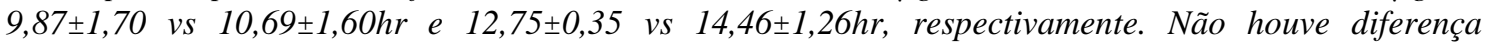
estatisticamente significante entre os perfis de PK de FFL para os porcos anestesiados e não anestesiados. Esse estudo sugere que (i) FFL penetrou rapidamente no pulmão e concentração da droga sofre queda mais veloz em plasma que líquido pulmonar, (ii) o perfil de PK de FFL em suínos não modificou após administração de agente anestésico.

Palavras-chave: agente anestésico, lavagem broncoalveolar, florfenicol, farmacocinética, pulmonar

Recebido em 28 de janeiro de 2017

Aceito em 30 de janeiro de 2018

*Autor para correspondência (corresponding author)

E-mail: lixianqiang89@sina.com 


\section{INTRODUCTION}

Bacterial pneumonia is common in modern pork production worldwide, which can cause great economic loss and increased mortality, morbidity (Li et al., 2016). Some prevalence surveys showed that the morbidity of pig pneumonia ranges from $10 \%$ to $45 \%$ and mortality from $2 \%$ to $20 \%$ (Hansen et al., 2010). The research has also been shown that the average daily gain (ADG) of affected pigs was reduced by $12.7 \%$ 15.9\%, while the feed efficiency was reduced by $13.8 \%$ (Pointon et al., 1985), a $10 \%$ increase in the volume of pneumonic lungs and it was associated with a decrease in daily weight gain by 41.1g (Hill et al., 1992). Florfenicol (FFL), a fluorinated derivative of thiamphenicol, has a broad antibacterial spectrum similar to chloramphenicol and has a stronger antibacterial activity than thiamphenicol (Cannon et al., 1990). It is intensively used to control the porcine respiratory disease due to the excellent antibacterial activity against the main primary causative bacteria such as Pasteurella multocida, Actinobacillus Pleuropneumoniae, Streptococcus suis, Bordetella bronchiseptica, Haemophilus parasuis, etc (Priebe \& Schwarz, 2003; Shin et al., 2005; Li et al., 2016).

Although the pharmacokinetic (PK) of FFL has been extensively studied in veal calves (Varma et al., 1986), cows (Soback et al., 1995), goats (Verma et al., 2009), sheep (Lane et al., 2004), pigs (Liu et al., 2003; Kim et al., 2008; Li et al., 2016), dogs (Park et al., 2008) and broiler chickens (Shen et al., 2003),, reports concerning the PK in the pulmonary tissue are quite few. As we know, the main primary causative bacteria of the pneumonia always could be isolated from the upper respiratory tract such as the tonsils of both infected and healthy animals (Vaillancourt et al., 2015). Furthermore, FFL may accumulate in a respiratory organs, with the result that the drug concentration at pulmonary tissue was always higher than that in plasma/serum (Afifi \& Abo elSooud, 1997). So, the prediction of drug concentrations in the lungs from simple extrapolation of the unbound drug fraction in plasma/serum is always not very precise. In addition, knowledge regarding the drug concentrations at a target sites is very important to increase the efficacy of therapeutic interventions and in selection of new drug candidates, several studies have shown that the drug concentrations in the target sites were directly correlated with the clinical efficacy (Barbour et al., 2010). Therefore, it has practical significance to conduct the PK of FFL in pulmonary tissue.

The pulmonary epithelial lining fluid (PELF) the most important target site for lung infections, and bronchoaveolar lavage (BAL) is an interesting technique for detecting a variety of pulmonary disorders and studying the concentrations of various solutes in the epithelial fluid that lines the surface of the lung (Lee et al., 2015), and it has been frequently used to establish an intrapulmonary PK model. In this study, the purpose was to describe the FFL kinetic disposition in both the plasma and pulmonary tissue at $20 \mathrm{mg} / \mathrm{kg}$ dosage after intramuscular for comparing the PK parameters at the two different tissue and evaluate the effect of anesthesia with ketamine and propofol on the PK of FFL in plasma.

\section{MATERIALS AND METHODS}

FFL injection $(0.3 \mathrm{~g} / \mathrm{m} l)$ was obtained from Zhejiang Guobang Pharmaceutical Factory Co., Ltd (Zhejiang, China). Atropine injection, ketamine injection and propofol solution were donated from Key Laboratory of Tarim Animal Husbandry Science and Technology of Xinjiang Production \& Construction Corps. Ammonia, ethyl acetate and dimethylformamide (DFM) were purchased from Aladdin Biological Engineering Technology \& Services Co., Ltd (Shanghai, China). Acetonitrile with liquid chromatography grade were provided by TEDIA (USA). The water for HPLC was prepared with a Milli-Q system. Other chemicals and reagents not specified in the text were of analytical grade or equivalent.

Eighteen healthy castrated crossbred (Duroc $x$ Large White $\times$ Landrace) pigs (body weight $16 \pm 2 \mathrm{~kg}$ ) were obtained from experimental station of Tarim University (Alar, Xinjiang, China). The animals were housed in laboratory animal rooms of Tarim University's Animal Teaching Hospital for 7 days to acclimatize. During acclimatization periods, the pigs were kept on basal feed twice daily and water available ad libitum around the clock without any drugs and contaminants. The breed environment temperature and relative humidity 
were kept at $15 \sim 20^{\circ} \mathrm{C}$ and $80 \sim 90 \%$, respectively. After the final sampling, all pigs were immediately euthanized and all experiments protocols concerning the handling of pigs were in accordance with the requirements of the experimental animal ethics/Ethics Committee Animal Science Academy of Xinjiang Uygur Autonomous Region.

Atropine injection $\quad(0.05 \mathrm{mg} / \mathrm{kg}) \quad$ was intramuscular administration for reducing the airway mucus before anesthetic medication. After that the ketamine injection $(5 \mathrm{mg} / \mathrm{kg})$ was given intramuscularly to get a shallow sedation anesthesia and then intravenous bolus injection administration of the propofol solution $(3 \mathrm{mg} / \mathrm{kg})$ for general anesthesia. When the pig was completely unconscious, the fiberoptic bronchoscopy (KangmeiGU-180VET) with BAL was performed according to a standardized protocol described previously (Choi et al., 2012; Villarino et al., 2013; Villarino and MartínJiménez, 2013). Briefly, three consecutive aliquots $(10,20$, and $30 \mathrm{~mL})$ of sterile saline solution were instilled into the right middle lobe by the flexible fiber-optic endoscope and the probe following the bronchi until resistance was met. The probe was uncovered from the protective sheath and was visually placed in contact with the bronchus wall for approximately $20 \mathrm{sec}$, and then the fluid retrieved was collected into a $50 \mathrm{~m} l$ centrifugal tube, transported on wet ice $\left(\sim 0^{\circ} \mathrm{C}\right)$ and stored at $-20^{\circ} \mathrm{C}$ for analysis by High Performance Liquid Chromatography (HPLC).

The urea dilution method was used to determine the volume of PELF as described previously (Choi et al., 2012; Lee et al., 2015; Zhang et al., 2016), which based on the concentration of urea in PELF is considered to be same as the serum urea concentration implying complete distribution. The concentration of urea in plasma and PELF were determined by the ureaseglutamate dehydrogenase enzymatic method with an automatic biochemical analyzer (synchroncx4pro; Beckman) at the Tarim University's Animal Teaching Hospital (Alar, Xinjiang, China). And the volume of PELF is adjusted for excess exogenous water using the following equation (Kiem \& Schentag, 2008): $\mathrm{V}_{\mathrm{PELF}}=\mathrm{V}_{\mathrm{BAL}} \times \mathrm{Urea}_{\mathrm{BAL}} / \mathrm{Urea}_{\text {serum}}$, where Urea $\mathrm{BAL}_{\mathrm{B}}$ and Urea $_{\text {serum }}$ are the concentrations of urea in BAL fluid and serum, respectively.
Eighteen pigs were randomly divided into 3 groups with 6 animals in each group (first group for plasma PK study without anesthesia, second group for plasma PK study with anesthesia and another group for pulmonary PK study). The approved label dose $(20 \mathrm{mg} / \mathrm{kg})$ of FFL injection was intramuscularly administrated to one side of the neck of the pigs. At different time points $(0$, $0.25,0.5,0.75,1,2,4,6,9,12,24,36$ and $48 \mathrm{hr}$ for blood samples, $0.5,2,4,6,9,12,24,36,48$, 72, and 96hr for PELF samples) post administration, blood samples $(1 \mathrm{~m} l)$ were taken from anterior vena cava and PELF samples were collected by BAL. Plasma was separated from blood by centrifugation at $3000 \times \mathrm{g}$ for $10 \mathrm{~min}$ and was kept at $-70^{\circ} \mathrm{C}$ until assay, and the PELF was centrifuged at $400 \times \mathrm{g}$ for $10 \mathrm{~min}$ and stored at $70^{\circ} \mathrm{C}$ until analysis. The drug levels in plasma and PELF all were determined by HPLC. The data on plasma and pulmonary drug concentrations-time were analyzed by using the Winnonlin (Version 5.2.1, Pharsight Corporation, Mountain View, CA, USA) computer software.

FFL were quantified using a Waters 2695 series HPLC and a Waters 2587UV detector set at a wavelength of $254 \mathrm{~nm}$. The chromatographic separation was achieved with an analytical ZORBAX SB C18 column $(250 \times 4.6 \mathrm{~mm}$, i.d. $5 \mu \mathrm{m}$; Agilent Technology, USA) at $25^{\circ} \mathrm{C}$. The mobile phase of FFL was acetonitrile and $0.1 \%$ ammonia solution with the proportion of $25 / 75$ $(\mathrm{V} / \mathrm{V})$. The flow rate and injection volume of the drug were $1 \mathrm{~m} / / \mathrm{min}$ and $20 \mu l$.

Plasma $(0.2 \mathrm{~m} l)$ was extracted with ethyl acetate $(0.4 \mathrm{~m} l)$ twice. After centrifugation, supernatant was evaporated and resuspended in the mobile phase $(0.2 \mathrm{~m} l)$. PELF $(0.5 \mathrm{~m} l)$ was extracted with DFM $(2 \mathrm{ml})$, and then centrifuged, evaporated and resuspended in a same manner. The limit of determination (LOD) was $0.02 \mu \mathrm{g} / \mathrm{m} l$ and the limit of quantification (LOQ) was $0.03 \mu \mathrm{g} / \mathrm{m} l$ both in plasma and PELF. Standard curves were linear from 0.03 to $10 \mu \mathrm{g} / \mathrm{ml}$ both in plasma $\left(R^{2}=0.9999\right)$ and PELF $\left(R^{2}=0.9998\right)$. The interday variation for determination in plasma ranged from 0.68 to $1.03 \%$ and PELF 0.17 to $0.82 \%$, respectively. The recovery of FFL in plasma ranged from $91.09 \pm 2.15 \%$ to $93.27 \pm 1.58 \%$ and in PELF from $97.49 \pm 1.26$ to $98.33 \pm 0.94 \%$, respectively. 
Data are presented as mean \pm S.D. (standard deviation). The Prism 5.0 software (GraphPad Software, San Diego, Calif.) was used to perform statistical analysis, data processing as well as the graph representation. In each case, a two-tailed t test was used to assess the significance of difference in the PK parameter values between the PELF, plasma with anesthesia and plasma without anesthesia. A $P$ value of 0.05 was regarded as significant.

\section{RESULTS}

Blood samples at all time points were eligible for analysis. Both plasma and pulmonary drug concentration-time profiles of FFL were illustrated in Table 2 and Figure 1. After intramuscular administration, the FFL in plasma without anesthesia and with anesthesia were reached to the peak concentrations of $4.73 \pm 0.42 \mu \mathrm{g} / \mathrm{ml}$ at $3.33 \pm 1.03 \mathrm{hr}$ and $4.65 \pm 0.34 \mu \mathrm{g} / \mathrm{ml}$ at $3.67 \pm 0.82 \mathrm{hr}$, and then maintained above the LOQ of $0.03 \mu \mathrm{g} / \mathrm{m} l$ for $36 \mathrm{hr}$ and $48 \mathrm{hr}$, respectively. The main PK parameters were depicted in Table 2. The area under the concentration-time curve $\left(\mathrm{AUC}_{0-\mathrm{t}}\right)$, elimination half-life $\left(\mathrm{T}_{1 / 2 \mathrm{ke}}\right)$ and mean residence time (MRT) of FFL in plasma without anesthesia and with anesthesia were $61.31 \pm 4.14 \quad v s$ $69.45 \pm 4.36 \mu \mathrm{g} \cdot \mathrm{hr} / \mathrm{ml}, 7.89 \pm 0.95$ vs $9.87 \pm 1.70 \mathrm{hr}$ and $10.36 \pm 0.42$ vs $12.75 \pm 0.35 \mathrm{hr}$, respectively. And there was no statistically significant difference between the PK profiles of FFL for the anesthetized and unanesthetized pigs.

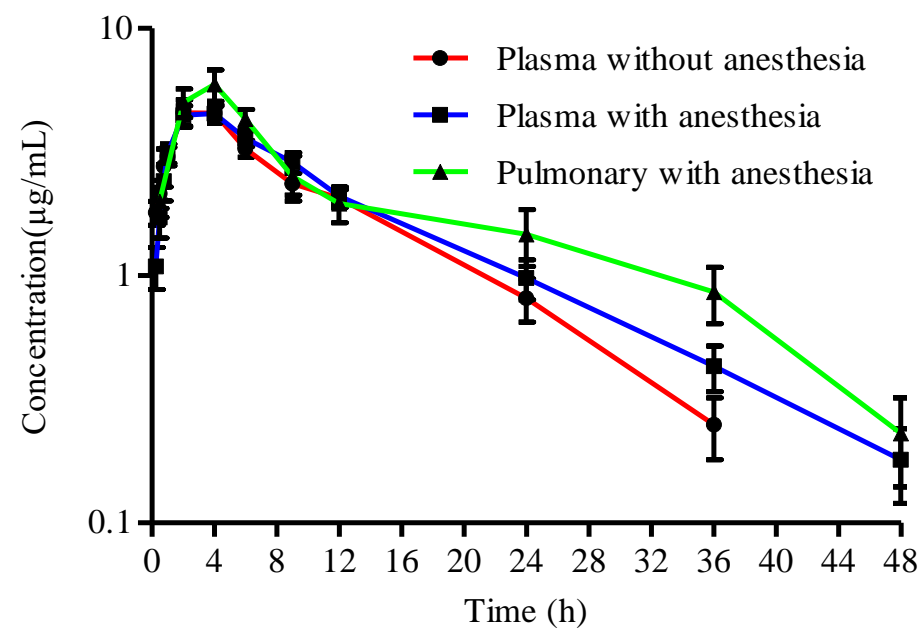

Figure 1. Semi-logarithmic plots of florfenicol in plasma and pulmonary following intramuscular administration of a single dose of $20 \mathrm{mg} / \mathrm{kg}$ body weight in pigs. Drugs concentrations were expressed means \pm standard deviations $(n=6)$.

The urease-glutamate dehydrogenase enzymatic in PELF samples at all time points was eligible for determination, and the concentration of urea in plasma and PELF at all time points was illustrated in Table 1. The urea concentration in plasma of pre-administration group was $5.38 \pm 0.49 \mathrm{mmol} / l$, and the urea concentration in PELF of all time points was $0.49 \pm 0.07 \mathrm{mmol} / l$, respectively. As shown in Table 1, the concentration of FFL in PELF was diluted about 10 times by sterile saline solution compare to the drug concentration in plasma through the urea dilution method.
Anesthesia scheme was qualified for PELF sampling in the pulmonary PK study and all PELF samples were eligible for analysis. After drug administration, FFL in PELF was reached to the peak concentrations of $5.94 \pm 0.86 \mu \mathrm{g} / \mathrm{ml}$ at $4.33 \pm 0.82 \mathrm{hr}$, then decreased slowly and sustained about $0.23 \mu \mathrm{g} / \mathrm{m} l$ for $48 \mathrm{hr}$. As shown in Table 1, the main PK parameters such as $\mathrm{AUC}_{0-\mathrm{t}}$, $\mathrm{T}_{1 / 2 \mathrm{ke}}$ and MRT of FFL in PELF were $85.03 \pm 9.26 \mu \mathrm{g} \cdot \mathrm{hr} / \mathrm{ml}, \quad 10.69 \pm 1.60 \mathrm{hr} \quad$ and $14.46 \pm 1.26 \mathrm{hr}$, respectively. 
Table 1 Urea concentration in BALF and plasma $(\mathrm{mmol} / \mathrm{l})$

\begin{tabular}{|c|c|c|c|c|c|c|}
\hline Time & $1 \#$ & 2\# & 3\# & 4\# & $5 \#$ & 6\# \\
\hline \multicolumn{7}{|c|}{ Urea concentration in BALF $(\mathrm{mmol} / l)$} \\
\hline $0.5 \mathrm{hr}$ & 0.48 & 0.42 & 0.49 & 0.41 & 0.39 & 0.41 \\
\hline $2 \mathrm{hr}$ & 0.51 & 0.37 & 0.41 & 0.35 & 0.45 & 0.46 \\
\hline $4 \mathrm{hr}$ & 0.46 & 0.52 & 0.48 & 0.52 & 0.51 & 0.53 \\
\hline $6 \mathrm{hr}$ & 0.56 & 0.52 & 0.53 & 0.51 & 0.45 & 0.48 \\
\hline $9 \mathrm{hr}$ & 0.53 & 0.49 & 0.62 & 0.47 & 0.41 & 0.39 \\
\hline $12 \mathrm{hr}$ & 0.62 & 0.57 & 0.52 & 0.55 & 0.48 & 0.47 \\
\hline $24 \mathrm{hr}$ & 0.53 & 0.55 & 0.48 & 0.49 & 0.64 & 0.61 \\
\hline $36 \mathrm{hr}$ & 0.48 & 0.47 & 0.39 & 0.62 & 0.45 & 0.55 \\
\hline $48 \mathrm{hr}$ & 0.51 & 0.49 & 0.47 & 0.48 & 0.44 & 0.62 \\
\hline \multicolumn{7}{|c|}{ Urea concentration in plasma $(\mathrm{mmol} / l)$} \\
\hline & 4.72 & 5.97 & 5.59 & 5.66 & 4.83 & 5.49 \\
\hline
\end{tabular}

\section{DISCUSSION}

FFL was approved worldwide for the control of bacterial respiratory tract infections in pigs (Ali et al., 2003; Shin et al., 2005; Li et al., 2016. The PK of FFL has been extensively investigated in many species, including veal calves (Varma $e t$ al., 1986), cows (Soback et al., 1995), goats (Verma et al., 2009), sheep (Lane et al., 2004), pigs (Liu et al., 2003; Kim et al., 2008; Li et al., 2016), dogs (Park et al., 2008) and broiler chickens (Shen et al., 2003), but most previous PK studies only focused on the plasma/serum concentration of the active substance but ignored the concentrations of antimicrobial agents in its target sites. Nevertheless, drug concentrations at the site of infection are clinically relevant (Drusano, 2005), as it is broadly accepted that biophase drug kinetics is the primary controller in the antimicrobial response (Müller et al., 2004; Drusano, 2007).. Innovatively, the PKs parameters of FFL in both plasma and pulmonary tissue were analyzed in current study.

FFL deposition in plasma after the i.m. administration was well described by the onecompartment model with a first order absorption, exhibiting a markedly elongated the elimination half-life $\left(T_{1 / 2 k e}\right)$ and a high bioavailability, indicating that FFL underwent a slow elimination phase but a completely systematic utilization in both anesthetic and non-anaesthetic pigs. The $\mathrm{T}_{1 / 2 \mathrm{ke}}$ of FFL in plasma of unanaesthetic pigs calculated in the present study was $7.89 \pm 0.95 \mathrm{hr}$, similar to previous study of $9.35 \pm 1.32 \mathrm{hr} 32 \mathrm{hr}(\mathrm{Li}$ et al., 2016) and 5.29 $\pm 2.58 \mathrm{hr}$ (Kim et al., 2008) in pigs by the same route and dosage. And the area under the concentration-time curve $\left(\mathrm{AUC}_{0-\mathrm{t}}\right)$ was $61.31 \pm 4.14 \mu \mathrm{g} \cdot \mathrm{hr} / \mathrm{ml}$, in agreement with

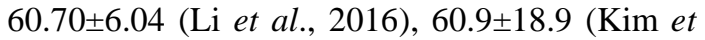
al., 2008) and $68.61 \pm 10.36 \mu \mathrm{g} \cdot \mathrm{hr} / \mathrm{ml}$ (Liu et al., 2003) in pigs. Maximal drug concentration $\left(\mathrm{C}_{\max }\right)$, time to reach $\mathrm{C}_{\max }\left(\mathrm{T}_{\max }\right)$ and the absorption half-life $\left(\mathrm{T}_{1 / 2 \mathrm{ka}}\right)$ value of $4.73 \pm 0.42 \mu \mathrm{g} / \mathrm{ml}, 3.33 \pm 1.03 \mathrm{hr}$ and $0.62 \pm 0.09 \mathrm{hr}$ obtained for unanaesthetic pigs weren't appear to be much different from the previous researches. Other PK parameters such as mean residence time (MRT), apparent volume of distribution $(\mathrm{Vd} / \mathrm{F})$ and the clearance rate $(\mathrm{Cl} / \mathrm{F})$ were significantly difference with previously reported that maybe due to the biases introduced by individual animals or pharmaceutical factors in the special formula as well as the analytical methods.

In respiratory conditions, the target tissue is the lung, in particular the extracellular fluid such as the epithelial lining fluid that covers the route of entry and colonization of microorganisms that cause pneumonia (Villarino et al., 2013). Concentrations of antibiotics in PELF for extracellular pathogens such as Actinobacillus Pleuropneumoniae are thought to reflect the antibiotic activity in pneumonia. Therefore, predictions about antibacterial efficacy shouldn't be performed by using plasma/serum drug concentrations as a surrogate for the drug concentration at the site of infection.

Moreover, it's important to note, the total antibiotic concentration measurements from tissue homogenate cannot be normally considered as valid, and results or interpretations based on them may be ambiguous. The main reason is that lung homogenate is a hybrid 
heterogeneous sample, as it encompasses multiple compartments. For most of the microorganisms, the actual target biophase is the interstitial space fluid; therefore, effective concentrations might be under or overestimated. BAL is an interesting technique for detecting a variety of pulmonary disorders and studying the concentrations of various solutes in the epithelial fluid that lines the surface of the lung (Lee et al., 2015), and it has frequently been used to establish an intrapulmonary PK model.

In PELF sampling, anesthesia was maintained for 10 20min in a different time points with ketamine injection and intermittently intravenous propofol solution. Statistical results show that there was no statistically significant difference between the PK profiles of FFL in plasma for the anesthetized and unanesthetized pigs shown in Table 2. Mostly, it has been suggested that the PK profile of FFL in PELF was not interfered after the administration of anesthetic agent with ketamine and propofol. FFL in PELF was swiftly reached to the $\mathrm{C}_{\max }$ of $5.94 \pm 0.86 \mu \mathrm{g} / \mathrm{ml}$ at about $4.3 \mathrm{hr}$, decreased slowly and continued for $48 \mathrm{hr}$. In contrast, the drug in plasma of anaesthetic pigs was more quickly reached to the $\mathrm{C}_{\max }$ of $4.65 \pm 0.34 \mu \mathrm{g} / \mathrm{ml}$ at $3.67 \pm 0.82 \mathrm{hr}$, and then declined rapidly below the LOD at $36 \mathrm{hr}$ post administration. This result suggested that the drug penetrated rapidly into the pulmonary, but concentration declined slowly. And the drug concentration decay faster in plasma than in the pulmonary. Furthermore, FFL concentration in the PELF exceeded that in plasma, this demonstrates that there is not a rapid drug equilibration between both compartments after $\mathrm{T}_{\max }$. And this result might indicate that different factors, other than/or in addition to simple drug diffusion, intervene in the process of movement of the FFL in and out between the plasma and the pulmonary compartments. Higher AUC $_{0-\mathrm{t}}, \quad \mathrm{MRT}, \mathrm{C}_{\max }$ and $\mathrm{T}_{1 / 2 \mathrm{ke}}$ could be obtained in PELF $(85.03 \pm 9.26 \mu \mathrm{g} \cdot \mathrm{hr} / \mathrm{ml}$, $14.46 \pm 1.26 \mathrm{hr}, \quad 5.94 \pm 0.86 \mu \mathrm{g} / \mathrm{ml}$ and $10.69 \pm 1.60 \mathrm{hr}$ ) when compared to plasma in anaesthetic pigs $\quad(69.45 \pm 4.36 \mu \mathrm{g} \cdot \mathrm{hr} / \mathrm{ml}$, $12.75 \pm 0.35 \mathrm{hr}, 4.65 \pm 0.34 \mu \mathrm{g} / \mathrm{ml}$ and $9.87 \pm 1.70 \mathrm{hr}$ ). In total, all these results suggest that FFL not only rapidly distributed in respiratory organs at high concentrations but also resided in epithelial lining fluid for a long time $(>48 \mathrm{hr})$. And this characteristic is exactly why the FFL could extensive used in worldwide for the prophylaxis and treatment of bacterial respiratory tract infections in pigs.

Table 2. PK parameters of florfenicol in plasma and PELF following intramuscular administration of a single dose of $20 \mathrm{mg} / \mathrm{kg}$ body weight in pigs. Values were means \pm standard deviations $(\mathrm{n}=6)$

\begin{tabular}{cccc}
\hline PK parameters & $\begin{array}{c}\text { Plasma without } \\
\text { anesthesia }\end{array}$ & $\begin{array}{c}\text { Plasma with } \\
\text { anesthesia }\end{array}$ & PELF with anesthesia \\
\hline $\mathrm{MRT}(\mathrm{hr})$ & $10.36 \pm 0.42$ & $12.75 \pm 0.35$ & $14.46 \pm 1.26^{*}$ \\
$\mathrm{AUC}_{0-24}(\mu \mathrm{g} \cdot \mathrm{hr} / \mathrm{m} l)$ & $54.66 \pm 3.42$ & $57.27 \pm 3.11$ & $64.53 \pm 5.83$ \\
$\mathrm{AUC}_{0-\mathrm{t}}(\mu \mathrm{g} \cdot \mathrm{hr} / \mathrm{m} l)$ & $61.31 \pm 4.14$ & $69.45 \pm 4.36$ & $85.03 \pm 9.26^{*}$ \\
$\mathrm{C}_{\max }(\mu \mathrm{g} / \mathrm{m} l)$ & $4.73 \pm 0.42$ & $4.65 \pm 0.34$ & $5.94 \pm 0.86^{*}$ \\
$\mathrm{~T}_{\max }(\mathrm{hr})$ & $3.33 \pm 1.03$ & $3.67 \pm 0.82$ & $4.33 \pm 0.82^{*}$ \\
$\mathrm{~T}_{1 / 2 \mathrm{ka}}(\mathrm{hr})$ & $0.62 \pm 0.09$ & $0.56 \pm 0.10$ & $0.76 \pm 0.12^{*}$ \\
$\mathrm{~T}_{1 / 2 \mathrm{ke}}(\mathrm{hr})$ & $7.89 \pm 0.95$ & $9.87 \pm 1.70 \#$ & $10.69 \pm 1.60^{*}$ \\
$\mathrm{Vd} / \mathrm{F}(l / \mathrm{kg})$ & $3.55 \pm 0.39$ & $3.47 \pm 0.49$ & $3.49 \pm 0.53$ \\
$\mathrm{Cl} / \mathrm{F}(l / \mathrm{hr} / \mathrm{kg})$ & $0.31 \pm 0.02$ & $0.26 \pm 0.02$ & $0.23 \pm 0.02$ \\
\hline
\end{tabular}

PK: pharmacokinetic; PELF: pulmonary epithelial lining fluid; MRT: mean residence time; $\mathrm{AUC}_{0-24}$ : the area under the concentration-24hr curve; $\mathrm{AUC}_{0-\mathrm{t}}$ : the area under the concentration-time curve; $\mathrm{C}_{\max }$ : maximal drug concentration; $\mathrm{T}_{\max }$ : time to reach $\mathrm{C}_{\max } ; \mathrm{T}_{1 / 2 \mathrm{ka}}$ : the absorption half-life; $\mathrm{T}_{1 / 2 \mathrm{ke}}$ : the elimination half-life; $\mathrm{Vd} / \mathrm{F}$ : apparent volume of distribution; $\mathrm{Cl} / \mathrm{F}$ : clearance rate.

*Statistical significances compared with plasma with anesthesia are $P<0.05$;

\# Statistical significances compared with plasma without anesthesia are $P<0.05$;

It is of interest that, whilst FFL has been in widespread use in pig industry for 20 years and whilst resistance occurrence and mechanisms have been described (Kehrenberg et al., 2004; Schwarz et al., 2004; it have been documented that FFL have a high level of activity against Actinobacillus Pleuropneumoniae, Haemophilus parasuis, Pasteurella multocida, etc with MIC ranging between 0.25 and $0.5 \mu \mathrm{g} / \mathrm{m} l$ (Sidhu et al., 2009; Li et al., 2016). Basically, present study 
demonstrated that average FFL concentrations in

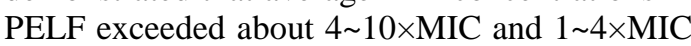
for a periods between $0-12$ and $24-48 \mathrm{hr}$, respectively. In addition, FFL was classified as typical concentration-dependent drug (Sidhu et al., 2009), the initially reported AUC/MIC and $\mathrm{C}_{\max } / \mathrm{MIC}$ are a better predictors than $\mathrm{T}>\mathrm{MIC}$ for the antibacterial effect, and on the basis of the FFL concentrations in PELF in present study and $\mathrm{MIC}$ report in literature, in vivo $\mathrm{AUC}_{24} / \mathrm{MIC}$ was about 130 260hr (Sang et al., 2016), which means that the dose of $20 \mathrm{mg} / \mathrm{kg} / \mathrm{bw}$ administered intramuscularly should be to ensure the success of therapy and preventing the emergence of resistance.

In conclusion, this study describes the disposition of FFL in PELF by use of the BAL technique and intrapulmonary model on the basis of our anesthesia method. PK of FFL in PELF in present study was demonstrated that FFL penetrated rapidly into the pulmonary and the drug concentration decay faster in plasma than in the pulmonary, and the PK profile of FFL in swine was not interfered after administration of anesthetic agent. This was considered to be acceptable, the risk of therapeutic failures and antimicrobial resistance to FFL could be reduced using the optimized dosage regimens based on these data. At the same time, this means of pulmonary PK studying and anesthesia protocols have leading meaning and practicality value to research and develop other antibiotics for respiratory infections.

\section{ACKNOWLEDGEMENTS}

This article was supported by the National Natural Science Foundation of China (31660729) and the Youth Program for Scholar and Innovative Research Teams in Tarim University (TDZKQN201603). Scientific and technical help from the staff in the laboratories of Key Laboratory of Tarim Animal Husbandry Science and Technology of Xinjiang Production \& Construction Corps is gratefully acknowledged in this study.

\section{REFERENCES}

AFIFI, N.A.; ABO-ELSOOUD, K.A. Tissue concentrations and pharmacokinetics of florfenicol in broiler chickens. Br. Poult. Sci., v.38, p.425-428, 1997.
ALI, B.H.; AL-QARAWI. A.A.; HASHAAD, M. Comparative plasma pharmacokinetics and tolerance of florfenicol following intramuscular and intravenous administration to camels, sheep and goats. Vet. Res. Commun., v.27, p.475-483, 2013.

BARBOUR, A.; SCAGLIONE, F.; DERENDORF, H. Class-dependent relevance of tissue distribution in the interpretation of anti-infective pharmacokinetic/pharmacodynamic indices. Int. J. Antimicrob. Agents, v.35, p.431-438, 2010.

CANNON, M.; HARFORD, S.; DAVIES, J. A comparative study on the inhibitory actions of chloramphenicol, thiamphenicol and some fluorinated derivatives. J. Antimicrob. Chemother., v.26, p.307317, 1990.

CHOI, S.H.; HONG, S.B.; KO, G.B. et al. Viral infection in patients with severe pneumonia requiring intensive care unit admission. Am. J. Resp. Crit. Care, v.186, p.325-332, 2012.

DRUSANO, G.L. Infection site concentrations: their therapeutic importance and the macrolide and macrolide-like class of antibiotics. Pharmacotherapy, v.25, p.150S-158S, 2015.

DRUSANO, G.L. Pharmacokinetics and pharmacodynamics of antimicrobials. Clin. Infect. Dis., v.45, Suppl.1, p.89-93, 2007.

HANSEN, M.S.; PORS, S.E.; JENSEN, H.E. et al. An investigation of the pathology and pathogens associated with porcine respiratory disease complex in Denmark. J. Comp. Pathol., v.143, p.120-131, 2010.

HILL, M.A.; SCHEIDT, A.B.; TECLAW, R.F. et al. Association between growth indicators and volume of lesions in lungs from pigs at slaughter. Am. J. Vet. Res., v.53, p.2221-2223, 1992.

KEHRENBERG, C.; MUMME, J.; WALLMANN, J. et al. Monitoring of florfenicol susceptibility among bovine and porcine respiratory tract pathogens collected in Germany during the years 2002 and 2003. J. Antimicrob. Chemother., v.54, p.572-574, 2004.

KEHRENBERG, C.; SCHWARZ, S. Plasmid-borne florfenicol resistance in Pasteurella multocida. $J$. Antimicrob. Chemother., v.55, p.773-775, 2005.

KIEM, S.; SCHENTAG, J. Interpretation of antibiotic concentration ratios measured in epithelial lining fluid. Antimicrob. Agents Chemother., v.52, p.24-36, 2008.

KIM, M.H.; GEBRU, E.; CHANG, Z.Q. et al. Comparative pharmacokinetics of tylosin or florfenicol after a single intramuscular administration at two different doses of tylosin-florfenicol combination in pigs. J. Vet. Med. Sci., v.70, p.99-102, 2008. 
LANE, V.M.; WETZLICH, S.; CLIFFORD, A. et al. Intravenous and subcutaneous pharmacokinetics of florfenicol in sheep. J. Vet. Pharmacol. Ther., v.27, p.191-196, 2004.

LANE, V.M.; WETZLICH, S.; CLIFFORD, A. et al. Intravenous and subcutaneous pharmacokinetics of florfenicol in sheep. J. Vet. Pharmacol. Ther., v.27, p.191-196, 2004.

LEE, J.Y.; PARK, H.J.; KIM, Y.K. et al. Cellular profiles of bronchoalveolar lavage fluid and their prognostic significance for non-HIV-infected patients with Pneumocystis jirovecii pneumonia. J. Clin. Microbiol., v.53, p.1310-1316, 2015.

LI, X.; XIE, S.; PAN, Y. et al. Preparation, characterization and pharmacokinetics of doxycycline hydrochloride and florfenicol polyvinylpyrroliddone microparticle entrapped with hydroxypropyl- $\beta$ cyclodextrin inclusion complexes suspension. Colloid. Surf. B, v.141, p.634-642, 2016.

LIU, J.; FUNG, K.F.; CHEN, Z. et al. Pharmacokinetics of florfenicol in healthy pigs and in pigs experimentally infected with Actinobacillus pleuropneumoniae. Antimicrob. Agents Chemother., v.47, p.820-823, 2013.

MÜLLER, M.; PEÑA, A.D.; DERENDORF, H. Issues in Pharmacokinetics and pharmacodynamics of antiinfective agents: distribution in Tissue. Antimicrob. Agents Chemother., v.48, p.1441-1453, 2004.

PARK, B.K.; LIM, J.H.; KIM, M.S. et al. Pharmacokinetics of florfenicol and its metabolite, florfenicol amine, in dogs. Res. Vet. Sci., v.84, p.8589, 2008

POINTON, A.M.; HEAP, P.; MCCLOUD, P. Enzootic pneumonia of pigs in South Australia-factors relating to incidence of disease. Aust. Vet. J., v.62, p.98-101, 1985.

PRIEBE, S.; SCHWARZ, S. In vitro activities of florfenicol against bovine and porcine respiratory tract pathogens. Antimicrob. Agents Chemother., v.47, p.2703-2705, 2013.

SANG, K.; HAO, H.; HUANG, L. et al. Pharmacokinetic- pharmacodynamic modeling of enrofloxacin against escherichia coli in broilers. Front. Vet. Sci., v.2, p.80, 2016.
SCHWARZ, S.; KEHRENBERG, C.; DOUBLET, B. et al. Molecular basis of bacterial resistance to chloramphenicol and florfenicol. FEMS. Microbiol. Rev., v.28, p.519-542, 2004.

SHEN, J.; HU, D.; WU, X. et al. Bioavailability and pharmacokinetics of florfenicol in broiler chickens. $J$. Vet. Pharmacol. Ther., v.26, p.337-341, 2013.

SHIN, S.J.; SANG, G.K.; NABIN, R. et al. Evaluation of the antimicrobial activity of florfenicol against bacteria isolated from bovine and porcine respiratory disease. Vet. Microbiol., v.106, p.73-77, 2005.

SIDHU, P.K.; ILLAMBAS, J.; POTTER, T. et al. Pharmacokinetics and pharmacodynamics of florfenicol in calves. J. Vet. Pharmacol. Ther., v.32, p.67-68, 2009.

SOBACK, S.; PAAPE, M.J.; FILEP, R. et al. Florfenicol pharmacokinetics in lactating cows after intravenous, intramuscular and intramammary administration. J. Vet. Pharmacol. Ther., v.18, p.413417, 1995

VAILLANCOURT, K.; LEBEL, G.; FRENETTE, M. et al. Suicin 3908, a new lantibiotic produced by a strain of Streptococcus suis serotype 2 isolated from a healthy carrier pig. PLoS One, v.10, p.e0117245, 2015 .

VARMA, K.J.; ADAMS, P.E.; POWERS, T.E. et al. Pharmacokinetics of florfenicol in veal calves. J. Vet. Pharmacol. Ther., v.9, p.412-425, 1986.

VERMA, S.; AHMAD, A.H.; RAHAL, A. et al. Pharmacokinetics of florfenicol following single dose intravenous and intramuscular administration in goats. J. Appl. Anim. Res., v.36, p.93-96, 2009.

VILLARINO, N.; LESMAN, S.; FIELDER, A. et al. Pulmonary pharmacokinetics of tulathromycin in swine. Part 2: Intra-airways compartments. J. Vet. Pharmacol. Ther., v.36, p.340-349, 2013.

VILLARINO, N.; MARTÍN-JIMÉNEZ, T. Pharmacokinetics of macrolides in foals. J. Vet. Pharmacol. Ther., v.36, p.1-13, 2013.

ZHANG, P.; HAO, H.; LI, J. et al. The epidemiologic and pharmacodynamic cutoff values of tilmicosin against Haemophilus parasuis. Front. Microbiol., v.7, p.385, 2016. 